Volume 2, Issue 1-2 (Summer 2010)

\title{
Gillis Coignet and the Amsterdam Lottery of 1592: Locating an Extraor- dinary Night Scene
}

Norbert Middelkoop

Recommended Citation:

Norbert Middlekoop, "Gillis Coignet and the Amsterdam Lottery of 1592: Locating an Extraordinary Night Scene,” JHNA 2:1-2 (2010), DOI: 10.5092/jhna.2010.2.1.4

Available at https://jhna.org/articles/gillis-coignet-amsterdam-lottery-1592-locating-an-extraordinary-night-scene/

Published by Historians of Netherlandish Art: https://hnanews.org/

Republication Guidelines: https://jhna.org/republication-guidelines/

Notes: This PDF is provided for reference purposes only and may not contain all the functionality or features of the original, online publication. This is a revised PDF that may contain different page numbers from the previous version. Use electronic searching to locate passages. This PDF provides paragraph numbers as well as page numbers for citation purposes.

ISSN: 1949-9833 


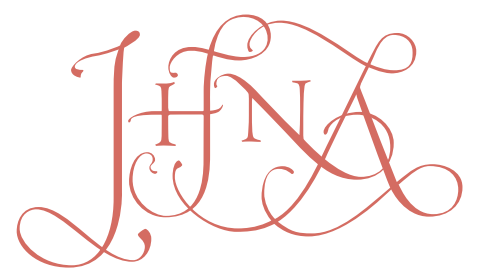

\section{GILLIS COIGNET AND THE AMSTERDAM LOTTERY OF 1592: LOCATING AN EXTRAORDINARY NIGHT SCENE}

\section{Norbert Middelkoop}

In 1592, the Flemish artist Gillis Coignet I (ca.1542-1599) produced a highly unusual painting for the Amsterdam Dolhuis (Madhouse) representing a nocturnal lottery organized to support the expansion of the building. This article investigates the iconography of the painting in relation to the historical circumstances surrounding this lengthy lottery (68 days and nights). It also places the painting in the context of (rare) depictions of current events. D0I: 10.5092/jhna.2010.2.1.4

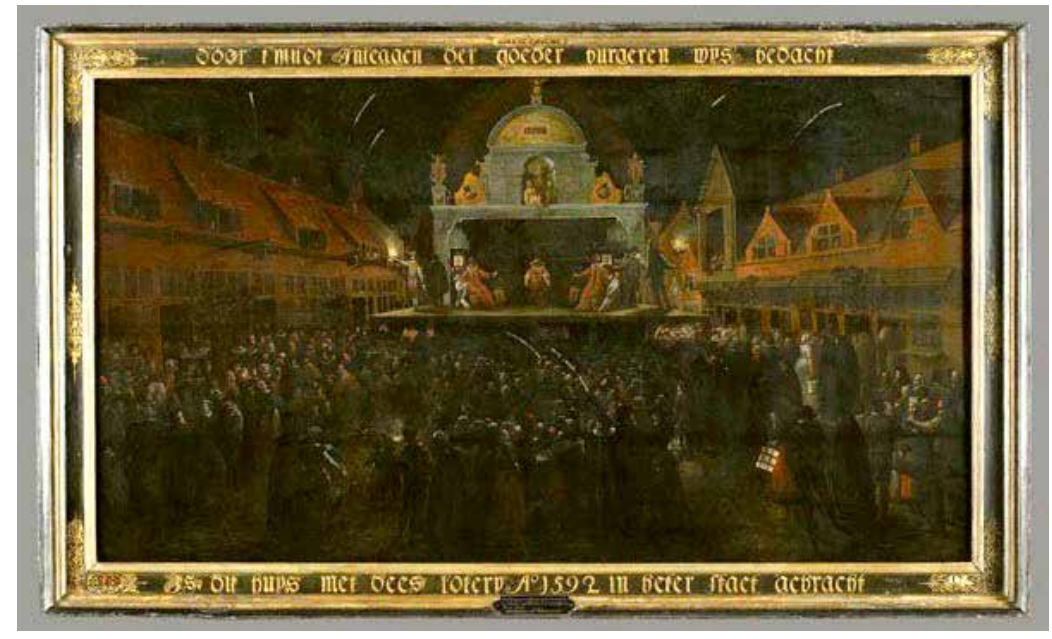

Fig. 1 Gillis Coignet I (ca. 1542-1599), The Drawing of the Lottery of 1592 for the Amsterdam Madhouse (Dolhuis), 1593, oil on panel, 113 x $203.5 \mathrm{~cm}$. Historisch Museum, Amsterdam, inv. no. SA 3019. Signed and dated at the bottom, left of center: "G coingnet fe. / in mey 1593." Image: Amsterdams Historisch Museum (artwork in the public domain) ike so many valuable possessions of disbanded municipal organizations, those of the Amsterdam Dolhuis (madhouse) ended up in the city's art collection during the nineteenth century. Among the paintings arriving at the town hall in 1873 was a large panel depicting a nighttime lottery that had been held in 1592, when the Dolhuis was expanded (fig. 1). The author of the painting remained unknown until 1888, when the signature and the date were discovered in the lower middle left of the panel: "G Coingnet fe. / in mey 1593." Because of its subject this exceptional painting has always been considered one of the most enigmatic works of the Amsterdams Historisch Museum. 
Gillis Coignet I (ca. 1542-1599) numbered among the many Flemish who, after the fall of Antwerp in 1585, were drawn to the north. Beginning in 1586, he lived and worked in Amsterdam for several years. The notation "mey 1593" on the painting is the last proof of Coignet's presence in the city. After 1595, he appears to have settled in Hamburg. Since the publication of Jan Briels's study of Flemish painters in the Northern Netherlands on the brink of the Golden Age (1987), Coignet has received more attention. ${ }^{2}$ Hessel Miedema, following his pioneering work on Karel van Mander, published two essays on the artist, discussing several individual works and compiling a list of paintings. ${ }^{3}$ In 1995, two of Coignet's paintings were included in the traveling exhibition Fiamminghi a Roma. ${ }^{4}$ Three years later, a documentary exhibition on the Coignet family was held in Antwerp. In the accompanying book, Ad Meskens summed up the current state of research on individual members, including Gillis I Coignet. ${ }^{5}$

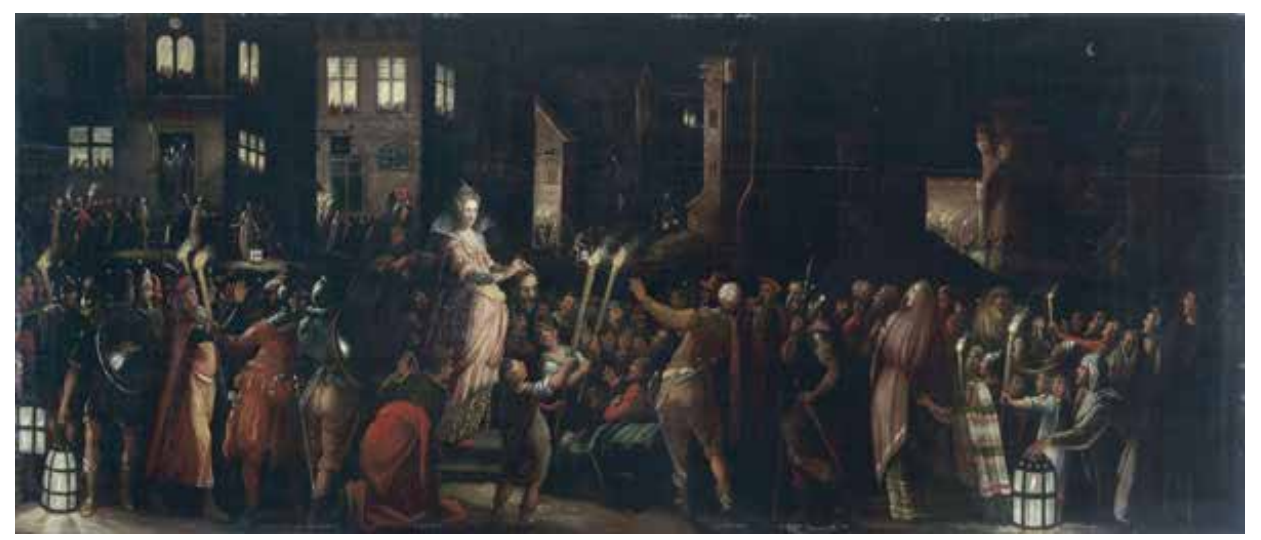

Fig. 2 Gillis Coignet I, Judith showing Holofernes's head to the people of Bethulia, 1586-1594, oil on panel, $62.5 \times 149$ cm. Musée des Beaux-Arts, Caen, inv. no. 2000.3.1 (artwork in the public domain)

Although the painting is one of the few signed and dated works by the artist, thus helping to shape the core of Coignet's oeuvre, no serious attention has been given to its remarkable iconography. The biographer Karel van Mander specifically refers to this panel in his praise of the artist's ability to paint convincing night scenes: "With paint he is miraculously able to let Pluto's territory burn or cause Troy to be destroyed or have Judith show Holofernes's head, with candles and torches as well as lanterns in the streets, the crowd gathering in the distance: as in the lottery that the governors of the Amsterdam Madhouse asked him to paint, not to mention other works of his." The first two themes mentioned by van Mander cannot be linked to any surviving paintings. ${ }^{7}$ However, as Miedema has demonstrated, "Judith showing Holofernes's head" most probably refers to the painting now in the Musée des Beaux-Arts in Caen (fig. 2). The last one mentioned is without doubt the painting in the Amsterdams Historisch Museum. Van Mander probably saw it in the Governors Room of the Dolhuis, where it was later viewed by Olfert Dapper in 1663 and Caspar Commelin in $1693 .{ }^{8}$ In the early 1760s, Jan Wagenaar, the city historian, encountered it in the Lady Governors Room. ${ }^{9}$

4 Judging from the inscription on the original frame, Coignet was commissioned to paint his nocturne as a commemoration of the lottery, an event held to celebrate the expansion of the Dolhuis: "Door ' $t$ mildt inleggen der goeder burgeren wys bedacht / Is dit huys met dees lotery A 1592 in beter staet gebracht" (By means of the gentle input of the good and wise citizens, this house was 
brought into a better state through this lottery $\left.A^{\circ} 1592\right)$. The institution had been established in 1562 with three thousand guilders left to the city by Hendrick Pouwelsz van Gisp (ca. 1495-1561), whose (presumed) portrait also belonged to the institution's inventory (fig. 3). Gisp decided to bequeath the sum after his pregnant wife was attacked by an insane woman. ${ }^{10}$ Once she delivered ahealthy child, he kept his vow and designated part of his money to the building of a madhouse after his death. The original structure soon proved too small, and on April 9, 1591, the city council approved the organization of a public lottery, the proceeds of which would be used for the extension of the Dolhuis. ${ }^{11}$ A print produced for the occasion contains the rules of the lottery as well as an overview of the prizes that could be won-an impressive amount of silver tableware combined with money-as well as an artist's impression of what the expanded building would look like (fig. 4). ${ }^{12}$ Lots priced at six pence each were sold for one year, then the drawing commenced on August 14, 1592. Despite what the inscription on the painting's frame would have us believe, the planned expansion of the Dolhuis was not completed until 1617 (fig. 5).



Fig. 3 Anonymous, Portrait of Hendrick Pouwelsz van Gisp (?), oil on panel, 41 x $29.5 \mathrm{~cm}$. Historisch Museum, Amsterdam, inv. no. SA 3006 (artwork in the public domain)

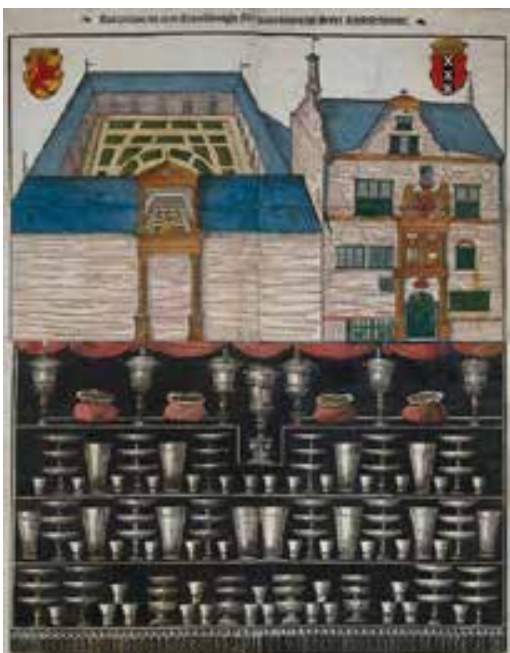

Fig. 4 Herman Jansz Muller, Lottery, 1591, colored woodcut, 74 x 58,5 cm. Rijksmuseum, Amsterdam. Image: Rijksmuseum



Fig. 5 Anonymous (J. van Meurs?), The Dolhuis after Its Renovation and Extension of 1617, from 0. Dapper, Beschrijvinge van Amsterdam (Amsterdam, 1663) (artwork in the public domain) 
Unfortunately, apart from the rules written on the lottery announcement, hardly anything is known about the Dolhuis lottery of 1592. Similar events in Leiden (1596) and Haarlem (1606-7) are much better documented and may serve as our basis for interpreting the painting. ${ }^{13}$ Coignet clearly presents the lottery drawing (fig. 6). A large crowd is gathered around a high podium in front of a backdrop crowned by an elegant Renaissance pediment that bears the date 1592 . In the central curved niche three men can be seen, possibly presenting a tableau vivant of the home's inmates. At the corners, winged figures hold the Amsterdam coat of arms. The stage itself is illuminated at the outer edges by two burning braziers, while the covered section is lit by lanterns. In the central foreground sit five colorfully dressed men: three lottery masters and two boys. The man in the middle has his sleeves rolled up to assert his important role in the drawing process. His active pose suggests that after each drawing he will shake the two huge containers on either side of him. One container, bearing the city's coat of arms, is probably filled with proosbriefjes (rhyme notes), each bearing a name and a short rhyme. The other contains both prize notes (for the lucky winners) and blank notes. Two teams, each consisting of a lottery master and a boy, perform the actual drawing: pulling rhyme notes from the container on one side and prizes and blanks from the other. Each team has a small basket at its disposal. The boys holding cloth bags are probably based on Haarlem and Leiden orphans, suggesting by their childish innocence that no skulduggery will occur during the drawing. The boy on the left is just handing a piece of paper to the lottery master, who will read it aloud. The men standing next to the braziers announce the outcome to the audience crowded around the stage. They must be the rhyme reader and the prize-and-blank-caller. The trumpeter to the right will blow his instrument to add luster to the winning of each prize.

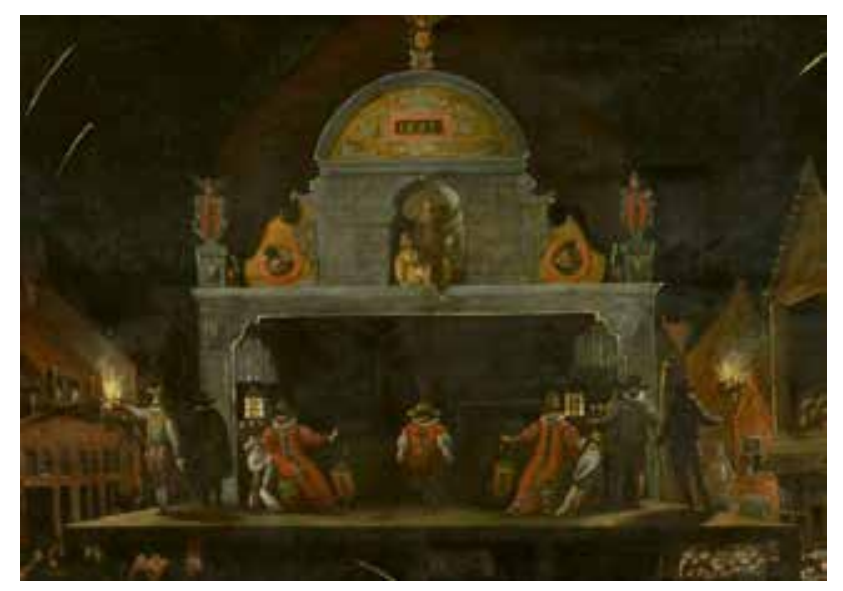

Fig. 6 Detail of figure 1. Image: Amsterdams Historisch Museum (artwork in the public domain)

On stage, several well-dressed men appear in the half darkness. Among them likely number the governors of the Dolhuis, the clerks who are administering the lottery, and the inspectors who ensure a flawless procedure. The two gentlemen looking down on the drawing from the round holes above are probably inspectors as well. The rules required that the controlling representatives of the city government (bailiff, burgomasters, sheriffs, and the thirty-six councillors) each take a turn providing oversight and be replaced every three hours. ${ }^{14}$ These individuals were assisted by a former sheriff and a governor of one of the almshouses. On the left side of the stage, a man climbs a ladder. Will he replace the man, visible at the back, who waits and looks straight toward 
him? All this monitoring does not prevent a rocket from the fireworks visible in the dark sky from falling among the people standing in front of the podium. Neither the advertised silverware nor any of the other prizes can be recognized in or around the temporary structure. Perhaps the prizes were kept elsewhere, as it was too dangerous to walk the street at night with valuables. ${ }^{15} \mathrm{~A}$ list of prizes won, accompanied by the names of their winners, was customarily noted on a board hung in front of the stage in order to "allow anybody at all times to see, know, and read who won a prize."16 Like the trophies, this board is not visible in the painting.

7 Until most recently, it was assumed that the lottery drawing was located on the relatively wide Het Rusland, a street located one block south of the Dolhuis. ${ }^{17}$ In his study of lotteries in the Netherlands (1862), G. A. Fokker was the first to mention this street as the site of the 1592 lottery drawing, although archival sources are silent in this regard. ${ }^{18}$ Van Mander, Dapper, and Wagenaar also failed to mention the location, nor is it given in the inscription on the painting's frame. A comparison of the painting with Pieter Bast's detailed map of Amsterdam from 1597 (figs. 7a and b) shows that Het Rusland could not have been the location of Coignet's scene as the topography does not match the scene portrayed. ${ }^{19}$ However, if we proceed two canals farther west, the similarities with the painting are numerous: close examination reveals the small vegetable market on Oudezijds Voorburgwal as Coignet's setting. Looking at a detail from the map-the north being toward the lower right corner-one sees the Dolhuis in the lower left, next to the round wall tower. Het Rusland is located farther south; it is the wide street next to the bridge. The vegetable market is visible in the upper right, directly behind the Grote Vleeshal (large meat hall) on the Nes. The south side of the square is lined with a low row of houses with parallel roofs, the rear one slightly higher, like those visible on the left in the painting. A similar row of houses is seen on the right; behind them appear some buildings perpendicular to the row of facades. ${ }^{20}$ Even the four trees in Coignet's painting can be found on the map. Judging from the lottery scene, the covered market hall dominating the small square seems to have been adapted for the occasion by adding a temporary stage on a substructure that extends into the square. ${ }^{21}$ The dark silhouette behind the stage is the back facade of the meat hall, housed in the former Sint Pieter's chapel.

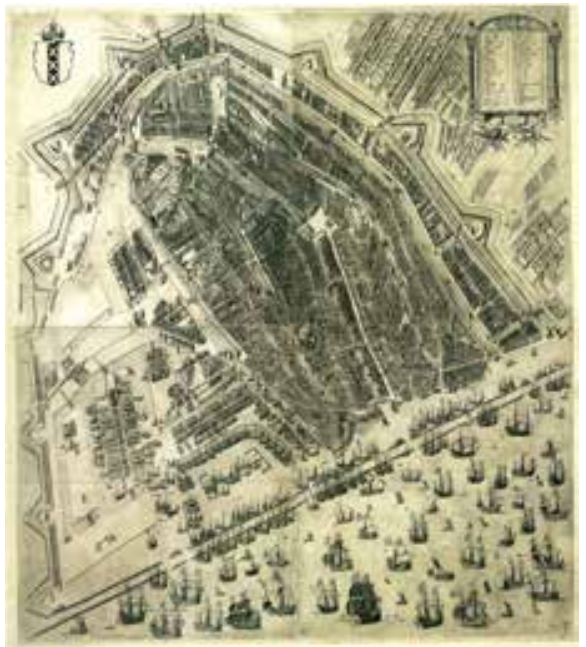

Fig. 7a Pieter Bast (ca. 1570-1605), Map of Amsterdam, 1597. Stadsarchief, Amsterdam, Atlas Splitgerber, inv. no. $10001 / 738$ (artwork in the public domain)

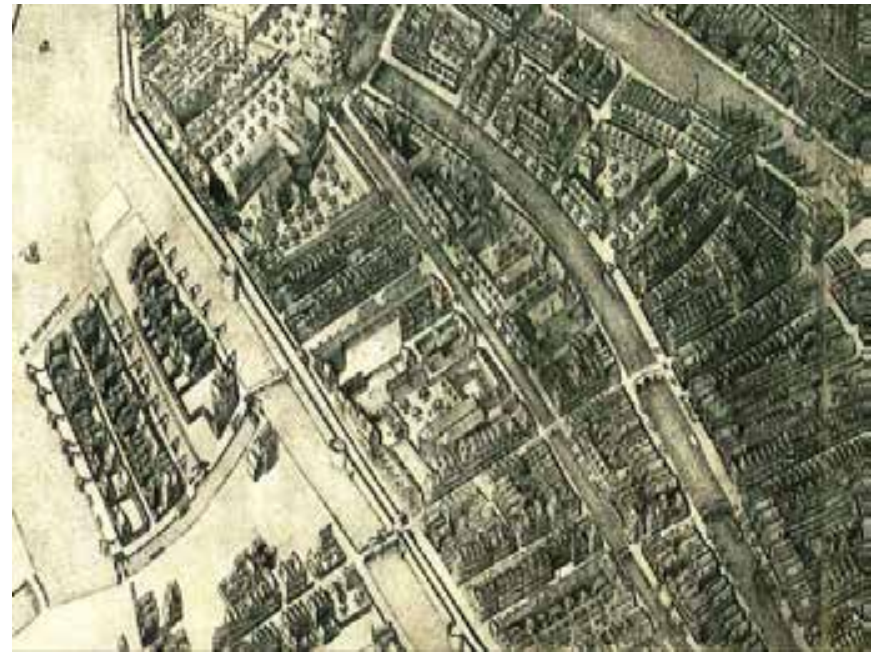

Fig. $7 b$ Detail of figure 6a (artwork in the public domain) 
A note by the historian Gerrit Pietersz Schaep (1599-1655) confirms the presumed location of the lottery drawing. ${ }^{22}$ He inserted a separate sheet in the pages dealing with the year 1592 in his unpublished Beschrijvinge (...) t' begin opkomen ende voortganc der Stad Aemsterdam ende bij gevolge van dien van alles t'gedencwardigste de Provincie van Hollant aengaende (Description of the beginnings, rise and progress of the City of Amsterdam and consequently of everything noteworthy concerning the Province of Holland). Schaep would have derived his information from an older source or based it on oral tradition. Although his historical records date from the middle of the seventeenth century, in this case there is no reason to doubt their credibility, given the topographical details of Coignet's night piece. In the same handwriting as the manuscript itself and on similar paper, the following appears:

\begin{abstract}
Anno 1592 was de Loterije voor t' dolhuijs. wierde gehouden inde Nes ontrent de oude Hall. vide figuram per Herman Jansz Figuersnijder inde Warmoestra[et] Begon getrocken te worden vande 14 Augustus s'ochtends ten 10 uren, tot 20 october. s'nachts ende daegs gedurende. de 2 Heeren wt de 36 Raden, ter presentie sittende, waren Laurens Jacobsz inde gouden Reael. Jan Verhee.
\end{abstract}

(Anno 1592 the lottery for the Dolhuis was held at the Nes near the Old Hall. See the print by Herman Jansz Figuersnijder, printmaker in the Warmoesstraet. The drawing began on August 14th at 10 oclock and lasted, day and night, until October 20.th The two representatives of the 36 councillors, present on that occasion, were Laurensz Jacobsz in the Gouden Reael and Jan Verhee.)

"Old Hall" refers to the meat hall (Sint Pieter's), already mentioned above. "Herman Jansz Figuersnijder"is the same person as Harmen Jansz Muller (ca. 1538-1617), who published the print showing the proposed Dolhuis, complete with the lottery rules and the available prizes. Despite its brevity, Schaep's note provides us with important information: the complete drawing lasted from August 14 to October 20. The lottery print states that it would last "without stopping, night and day, until every lot has been read." ${ }^{23}$ Likewise, the "instruction on the control of the Lottery for the insane people," issued a day before the start of the drawing, appears to take into account a lengthy procedure. ${ }^{24}$ On the authority of Fokker, it was always assumed that the event had taken one day and night or a few days at most. ${ }^{25}$ Now we know that the Amsterdam lottery took sixty-eight days and nights, lasting considerably longer than the lotteries in Leiden and Haarlem, both of which lasted fifty-two days and nights. ${ }^{26}$

10 Schaep also mentions two city councillors as being present at the drawing: Laurens Jacobsz Reael (1536-1601; council member 1583-1601) and Jan Cornelisz Verhee (1547-1599; council member 1583-99). ${ }^{27}$ Might we assume that these men were involved at the beginning of the drawing on the morning of August 14? Indeed, in the painting, the two men in hats peeping through the holes of the temporary structure on stage might well be the representatives of the city government, whose presence guaranteed a smooth and honest procedure. 
11 Paintings showing current events like this lottery representation are extremely rare in Netherlandish art. Yet a fairly large group of sixteenth-century Flemish prints does describe such major historical festivities as processions and the triumphal entries of rulers; and two prints after Pieter Breughel the Elder depict Antwerp kermises that took place around 1558-59. ${ }^{28}$ These scenes act as a prelude to the painted genre of the village kermis that flourished in the early seventeenth century, until about $1630 .{ }^{29}$ No doubt because of their familiarity with the prints, the artists who contributed to the genre in painting hailed from Flanders. Depictions of charity events in any medium were exceptional, however. In a village kermis scene by David Vinckboons, known from an authentic drawing dated 1602 (fig. 8) and from at least twelve painted studio versions, what might be a lottery can be discerned in the background. ${ }^{30}$ According to van Mander's life of the artist, Vinckboons devoted a full painting to the subject of a nighttime lottery in1603, Now lost, the painting was then in the brand new Amsterdam Oude Mannen- en -Vrouwen Gasthuis (Old Men's and Women's Hospital). ${ }^{31}$ Vinckboons must have known Coignet's older example, which was installed just a few blocks away. Nevertheless, of these two Flemish immigrants to Amsterdam, only Coignet was praised by the biographer for his night scenes, a skill that must have prompted the Dolhuis governors to approach him for the job. ${ }^{32}$


Fig. 9a Adriaen van Nieulandt, Dam Square with the Lepers' Parade, 1633, oil on canvas, $212 \times 308 \mathrm{~cm}$. Historisch Museum, Amsterdam, inv. no. SA 3026. Image: Amsterdams Historisch Museum (artwork in the public domain)
Fig. 8 David Vinckboons, Village Kermis, 1602, pen and ink, $45 \times 71,1 \mathrm{~cm}$. Statens Museum for Kunst, Copenhagen, inv. no. KKSgb5209 (artwork in the public domain)

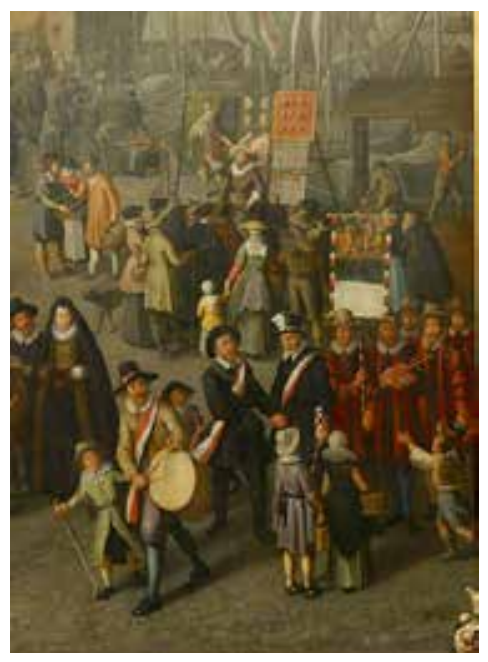

Fig. 9b Detail of figure 8a. Image: Amsterdams Historisch Museum (artwork in the public domain) 
12 Looking for more examples of "recent history" depictions in early seventeenth-century Dutch painting), we find a magnificent cityscape from 1633 by Adriaen van Nieulandt (figs. 9a and b). Dam Square is the backdrop for an event from the past: the Lepers' Parade on Koppertjes Monday, the first Monday after Epiphany (January 6). This was traditionally a day for the guilds to celebrate the new year with a parade, and in Amsterdam this overlapped with the annual Lepers' Parade. On that day inmates were allowed to leave the lepers' asylum to collect alms along the "Old Side" of town, and then the subsequent Tuesday along the "New Side." Due to the accompanying disorder, the city government abolished the annual procession in 1604. But remarkably, even as late as 1633, the governors of the lepers' asylum commissioned the painted commemoration of this yearly parade. Van Nieulandt depicted the moment at which the parade crosses Dam Square. A huge crowd watches the lepers pass by, even as ordinary life continues. Among these commonplace details, the lower right corner deserves our special attention. There a quack can be seen presenting his diploma, some bladder stones (the evidence of his skills), and pictures of satisfied customers. Closer to us a group wearing suits similar to those worn by the men in Coignet's Dolhuis lottery picture are led by a drummer and two city officials. The latter show off a banner with a picture of some lunatics and below it a list of prizes to be won and the proclamation of the lottery itself. As mentioned above, a promotional campaign just like this preceded the lottery of August 1592. It is tempting to assume that van Nieulandt's picture depicts the Lepers' Parade of Monday, January 13, 1592..$^{33}$ But here we have to be careful. The van Nieulandt painting was commissioned many years later, most likely to commemorate the annual historical event, rather than any particular iteration of the parade. ${ }^{34}$

13 To return to the Amsterdam Dolhuis (fig. 1), the evidence provided by Coignet and Schaep about the lottery's location invites one final observation. At the left behind the square, the chamber of rhetoricians known as De Eglentier had established its headquarters in 1583, occupying the top floor of the deconsecrated chapel of St. Margaret's Convent. ${ }^{35}$ Although difficult to distinguish against the dark sky, this building can be vaguely seen in the painting. On Bast's map it is much easier to distinguish, appearing south of the vegetable market. In 1591, De Eglentier, together with other Amsterdam rhetoricians, publicly performed the ambitious Seven Plays on the Works of Mercy. ${ }^{36}$ Past scholars have suggested a link between these plays and the Dolhuis lottery of the following year. Indeed, references are made to charity in some parts of the piece. ${ }^{37}$ As the selling of the lots lasted one year, it is not difficult to imagine the plays serving to whet the appetite for the lottery. And although there is no concrete evidence of cooperation between the rhetoricians and the Dolhuis, it is striking that Herman Jansz Muller was the publisher of both the Seven Plays and the lottery print. ${ }^{38}$ Since virtually nothing is known about sixteenth-century Amsterdam theater stages, we can only assume that the small-scale vegetable market, with its covered market hall, must have provided a convenient base not only for the Dolhuis lottery but for other outdoor performances as well. ${ }^{39}$ It can be hoped that future research will shed more light on these performances and events.

\section{Acknowledgements}

This article is based on previous publications by N. E. Middelkoop, "Gillis Coignet en de Dolhuisloterij van 1592," Maandblad Amstelodamum 95, 3/4 (2008): 2-8; and an addendum in Maandblad Amstelodamum 96, 4 (2009): 189-91, but for this occasion it was revised and enlarged with additional material and images. 
Since 1997 Norbert Middelkoop has been Curator of Paintings, Prints and Drawings at the Amsterdam Historical Museum. He has curated a number of exhibitions, for example, one on Amsterdam portraiture between 1600 and 1800 (2002), and contributed to many exhibition catalogues. Among his fields of research are Rembrandt's anatomy lessons and other paintings for the Amsterdam Surgeons' Guild. Recently, Middelkoop published the city of Amsterdam's collection catalogue of paintings up until 1800 , that includes many paintings on loan from the city to the Rijksmuseum. In 2009, the book was celebrated with a large exhibition dedicated to the history of the Old Masters collection.

\section{List of Illustrations}

Fig. 1 Gillis Coignet I (ca. 1542-1599), The Drawing of the Lottery of 1592 for the Amsterdam Madhouse (Dolhuis), 1593, oil on panel, 113 x $203.5 \mathrm{~cm}$. Historisch Museum, Amsterdam, inv. no. SA 3019. Signed and dated at the bottom, left of center: "G coingnet fe. / in mey 1593." Image: Amsterdams Historisch Museum (artwork in the public domain)

Fig. 2 Gillis Coignet I, Judith showing Holofernes's head to the people of Bethulia, 1586-1594, oil on panel, 62.5 x $149 \mathrm{~cm}$. Musée des Beaux-Arts, Caen, inv. no. 2000.3.1 (artwork in the public domain)

Fig. 3 Anonymous, Portrait of Hendrick Pouwelsz van Gisp (?), oil on panel, 41 x $29.5 \mathrm{~cm}$. Historisch Museum, Amsterdam, inv. no. SA 3006 (artwork in the public domain)

Fig. 4 Herman Jansz Muller, Lottery, 1591, colored woodcut, 74 x $58.5 \mathrm{~cm}$. Rijksmuseum, Amsterdam. Image: Rijksmuseum (artwork in the public domain)

Fig. 5 Anonymous (J. van Meurs?), The Dolhuis after Its Renovation and Extension of 1617, from O. Dapper, Beschrijvinge van Amsterdam (Amsterdam, 1663) (artwork in the public domain)

Fig. 6 Detail of figure 1. Image: Amsterdams Historisch Museum (artwork in the public domain)

Fig. 7a Pieter Bast (ca. 1570-1605), Map of Amsterdam, 1597. Stadsarchief, Amsterdam, Atlas Splitgerber, inv. no. 10001/738 (artwork in the public domain)

Fig. 7b Detail of figure 6a (artwork in the public domain)

Fig. 8 David Vinckboons, Village Kermis, 1602, pen and ink, 45 x $71.1 \mathrm{~cm}$. Statens Museum for Kunst, Copenhagen, inv. no. KKSgb5209 (artwork in the public domain)

Fig. 9a Adriaen van Nieulandt, Dam Square with the Lepers' Parade, 1633, oil on canvas, 212 x 308 $\mathrm{cm}$. Historisch Museum, Amsterdam, inv. no. SA 3026. Image: Amsterdams Historisch Museum (artwork in the public domain)

Fig. 9b Detail of figure 8a. Image: Amsterdams Historisch Museum (artwork in the public domain) 
${ }^{1} \mathrm{~N}$. de Roever, "De rariteiten-kamer verbonden aan 't Amsterdamsche Gemeente-archief," Oud Holland 6 (1888): 200.

${ }^{2}$ J. Briels, Vlaamse schilders in de Noordelijke Nederlanden in het begin van de Gouden Eeuw 1585-1630 (Haarlem: Brecht, 1987), 73-74.

${ }^{3}$ H. Miedema, "Nog een schilderij van Gillis Coignet: Judith toont het hoofd van Holofernes aan de inwoners van Bethulië," Oud Holland 109 (1995): 143-51. doi:10.1163/187501795X00223

${ }^{4}$ N. Dacos and B. W. Meijer, eds., Fiamminghi a Roma 1508-1608, exh. cat. (Rome: Istituto Poligrafico e Zecca dello Stato, 1995), 157-61, pls. 69-70.

${ }^{5}$ A. Meskens, Familia Universalis: Coignet; Een familie tussen wetenschap en kunst, exh. cat. (Antwerp: Koninklijk Museum voor Schone Kunsten, 1998), 30-50, 170-76.

${ }^{6}$ Met verwen can hy te wonder doen bernen / Plutonis stadt, oft Troyen doen te nieten, / Iudith snachts toonen t'hooft van Holofernen, / Met Toortsen en Fackels, oock met Lanternen / In de straten, t'volcx toeloop in 't verschieten: / Als de Lotery, die hem maken lieten / t'Amsterdam der Crancksinnighe vorstanders, / Sonder wat van hem noch te sien is anders": K. van Mander, "Den grondt der edel vry schilder-const," Schilder-boeck," ed. H. Miedema (Haarlem: 1604; repr., Utrecht: Haentjes Dekker \& Gumbert, 1973), fol. 32v., cap. VII, st. 42-44, esp. 44; see also Miedema,"Nog een schilderij van Gillis Coignet" (note 3), 145; and this page.

${ }^{7}$ J. Briels, Vlaamse schilders en de dageraad van Hollands Gouden Eeuw 1585-1630 (Antwerp: Mercator, 1997), 311-12, n. 9, mentions paintings by Coignet with those subjects in a Utrecht inventory of 1618 (Gemeentearchief Utrecht).

${ }^{8}$ O. Dapper, Beschrijvinge van Amsterdam (Amsterdam: J. van Meurs, 1663), 435; C. Commelin, Beschryvinge van Amsterdam (Amsterdam, 1693), 2:578.

${ }^{9}$ J. Wagenaar, Amsterdam, In Zyne Opkomst, Aanwas, Geschiedenissen, Voorregten, Koophandel, Gebouwen, Kerkenstaat, Schoolen, Schutterye, Gilden En Regeeringe (Amsterdam: Tirion, 1765), 308.

${ }^{10}$ Wagenaar, 307. For the history of the Dolhuis, see C. A. L. Sander, "Het Dulhuys of Dolhuis aan de vesten of de Kloveniersburgwal," Maandblad Amstelodamum 45 (1958): 229-38; G. Vermeer, "Het Dolhuis in Amsterdam en het tomen van de razernij," Idem 94, no. 5 (2007): 3-18.

${ }^{11}$ G. A. Fokker, Geschiedenis der loterijen in de Nederlanden (Amsterdam: F. Muller, 1862), 66-69 and 258-59. Sander, 234.

${ }^{12}$ For a full transcription of the lottery rules, see Fokker, 254-58. The print was illustrated without the text in Sander, 234; M. Spies, "Centrum van de wereld: 1587-1650," in Geschiedenis van Amsterdam, ed. W. Frijhoff and M. Prak (Amsterdam: Uitgeverij Boom, 2004), vol. 2-1:307; Vermeer (note 10), 8.

${ }^{13}$ For the Leyden lottery, see A. Huisman and J. Koppenol, Daer compt de Lotery met trommels en trompetten! Loterijen in de Nederlanden tot 1726 (Hilversum: Verloren, 1991), 41-50. For the Haarlem lottery, see K. Kilian, "De Haarlemse loterij van 1606-1607: Loterijen en loterijrijmpjes," Haerlem Jaarboek (1989): 8-37.

${ }^{14}$ Fokker (note 11), 67-68 and 259-60 ("instructie op 't waecken by de Lotery van de crancksinnige menschen").

${ }^{15}$ Ibid., in which the armed escort is mentioned for those officials overseeing the draw during nighttime hours.

${ }^{16}$ Fokker, 258: "Item soo wanneer eenighen Prys uytcomen sal dien men terstond te boecke stellen ende voorts schryven in een Taeffel, ende die Taeffele hangen voor ' $t$ Taneel, opdat een yegelyck tot allen tyden sien, weten, ende lesen mach, wien prijs ghebeurt of ghevallen is." 
${ }^{17}$ A. E. D’Ailly, "Het Rusland," Jaarboek Amstelodamum 32 (1935): 50-54, esp. 50; the date of the lottery even provided D'Ailly the terminus ante quem for the filling in of this former canal in 1592. ${ }^{18}$ Fokker, 67. His data were taken over in the Jaarverslag Gemeentearchief Amsterdam (Amsterdam, 1873), 20, when the painting entered the city's art collection.

${ }^{19}$ The map can be found in, among other publications, Het aanzien van Amsterdam: Panorama's, plattegronden en profielen uit de Gouden Eeuw, exh. cat., Amsterdam Stadsarchief, ed. B. Bakker and E. Schmitz (Bussum: Thoth, 2007-8),101-3, no. 8.

${ }^{20}$ On the large city map by Balthasar Florisz from 1625 (Het aanzien van Amsterdam, 103-9, no. 9) the square is described as the "Wortelmarkt"; the covered market hall has been considerably enlarged.

${ }^{21}$ This should not be confused with the nearby fish market on the square between the Grote en Kleine Vleeshallen (large and small meat halls) (visible in C. J. Visscher's print of 1611; Het aanzien van Amsterdam, 259-60, no. 60).

${ }^{22}$ Stadsarchief Amsterdam, toegangsnr. 5059 (collection of manuscripts), inv. no. 41. My special thanks to Erik Schmitz of the Stadsarchief who referred me to this citation.

${ }^{23}$ Fokker (note 11), 258: "sonder cesseren ofte ophouden / nacht / noch dach / voor dat alle die looten uytghelesen zyn."

${ }^{24}$ Ibid., 259-60.

${ }^{25}$ Fokker, 66, mentions “den 14den Augustus en volgende dagen” (August 14 and following days).

${ }^{26}$ See note 13.

${ }^{27}$ J. E. Elias, De Vroedschap van Amsterdam 1578-1795 (Haarlem and Amsterdam, 1903-5), 1:136-40, nos. 44-45.

${ }^{28}$ See D. P. Snoep, Praal en propaganda: Triumfalia in de Noordelijke Nederlanden in de 16e en 17e eeuw (Alphen a/d Rijn: Canaletto, 1975), 15-38; and N. M. Orenstein, Pieter Bruegel the Elder (The New Holstein...) (Ouderkerk aan de IJssel: Sound \& Vision, 2006), 100-106 (which also shows a skating scene outside St. George's Gate in Antwerp). My thanks to Huigen Leeflang, Rijksmuseum Amsterdam, for his remarks on the theme in sixteenth-century Flemish and Dutch prints.

${ }^{29}$ See for a discussion of the genre, see Briels (note 2), 116-28.

${ }^{30}$ Painted versions can be found (among other places) in Antwerp, Koninklijk Museum voor Schone Kunsten, panel, 110 x 167 cm (inv. no. 495) and Brunswick, Herzog Anton Ulrich-Museum (dated 1608), panel, $115 \times 141 \mathrm{~cm}$ (inv. no. 90). The detail under discussion might alternatively represent an open-air shop rather than a lottery.

Van Mander (note 6), fol. 299v.

${ }^{31}$ Van Mander (note 6), fol. 299v. (View Site): “Daer is oock van hem t'Amsterdam in 't oude Mannen Gasthuys, in 't Comptoor, een groot stuck, veerthien voeten langh en acht hoogh, wesende de Loterije voor t'selve Gasthuys, in der nacht, met de plaets en huysen nae t'leven, en alderley volck, met lanternen, en ander lichten, alles seer aerdigh en welghedaen: dit dede hy Ao. 1603." For the lottery (1600-1601) preceding this painting, see Fokker (note 11), 78-79. Both Dapper, 433, and Commelin, 572 (note 8) mention the painting; Wagenaar (note 9), 308, cites the remaining inscription stating that the painting is no longer there.

${ }^{32}$ Strikingly, neither artist is included in M. Neumeister, Das Nachtst, ck mit Kunstlicht in der niederländischen Malerei und Graphik des 16. und 17. Jahrhunderts (Petersberg: Michael Imhoff, 2003).

${ }^{33}$ Suggested earlier by Fokker (note 11), 198-99.

${ }^{34}$ See the entry on the painting in N. E. Middelkoop et.al., De oude meesters van de Stad Amsterdam: Schilderijen tot 1800 (Bussum: Thoth, 2008), 96-97. 
${ }^{35}$ This chamber has been referred to by its motto "In liefde bloeyende"; see E. Ellerbroek-Fortuin, Amsterdamsche rederijkersspelen in de zestiende eeuw (Groningen: Batavia, 1937), 24 vv. W. M. $\mathrm{H}$. Hummelen, Amsterdams toneel in het begin van de Gouden Eeuw: Studies over Het Wit Lavendel en de Nederduytsche Academie (The Hague, 1982), 25-27, argues that the Brabant chamber of rhetoricians, Het Wit Lavendel, did not use the same location, as suggested by J. W. Pontanus, Historische beschrijvinghe der seer wijt beroemde Coop-stadt Amsterdam (Amsterdam: J. Hondius, 1614), 149.

${ }^{36}$ Zeven spelen van die Wercken van Bermherticheyd. In rijm gemaeckt en nu tot Aemstelredam opentlijck ghespeelt, Anno 1591. T’Aemstelredam, bij mij Herman Jansz. Muller, figuersnijder, woonende in de Warmoesstaraat in den vergulden Passer, Anno 1591. See in general Spies (note 12), 305-7; for an extensive analysis, see Ellerbroek-Fortuin (note 35), 39-115.

${ }^{37}$ Ellerbroek-Fortuin, 63 and 94 . Toward the end of the third play references are made to the audience's generosity: "Wy doent so verre als ons wysheyt mach strecken / Uyt ionsten begeert dattet den armen mach baten' en het zesde spel besluit met de aansporingen 'Spaert gheenen cost voor de arme leden Christi' en 'Dus lieve Broeders en Susters draecht malcanderens last / En siet in tijt toe eer u die hant Gods verrast."

${ }^{38}$ Although Ellerbroek-Fortuin, 93-94, expresses some reservations about the link between the plays and the lottery, as suggested in the literature, Snoep (note 28), 33-34, refers to the painting as depicting "street theatre on the occasion of the Dolhuis lottery." See also Spies (note 12), 305-7, who supports this connection given the many other examples.

${ }^{39}$ Ellerbroek-Fortuin, 115-17, where the stage setting of the painting is discussed. D'Ailly (note 17), 54, assumed that the painting did not depict a lottery draw but a play.

\section{Bibliography}

Bakker, B. and E. Schmitz, eds. Het aanzien van Amsterdam: Panorama's, plattegronden en profielen uit de Gouden Eeuw. Exh. cat. Amsterdam, Stadsarchief. Bussum: Thoth, 2007-8.

Briels, J. Vlaamse schilders in de Noordelijke Nederlanden in het begin van de Gouden Eeuw 15851630. Haarlem: Brecht, 1987.

Briels, J. Vlaamse schilders en de dageraad van Hollands Gouden Eeuw 1585-1630, Antwerp: Mercator, 1997.

Commelin, C., Beschryvinge Van Amsterdam. 2 vols. Amsterdam, 1693.

Dacos, N., and B. W. Meijer, eds. Fiamminghi a Roma 1508-1608. Exh. cat. Rome: Istituto Poligrafico e Zecca dello Stato, 1995.

D’Ailly, A. E. “Het Rusland." Jaarboek Amstelodamum 32 (1935): 50--54.

Dapper, O. Beschrijvinge van Amsterdam. Amsterdam, 1663.

Ellerbroek-Fortuin, E. Amsterdamsche rederijkersspelen in de zestiende eeuw. Groningen: Batavia, 1937. 
Elias, J. E. De Vroedschap van Amsterdam 1578-1795. 2 vols. Haarlem and Amsterdam: 1903-5.

Fokker, G. A. Geschiedenis der loterijen in de Nederlanden. Amsterdam, 1862.

Huisman, A., and J. Koppenol. Daer compt de Lotery met trommels en trompetten! Loterijen in de Nederlanden tot 1726. Hilversum: Verloren, 1991.

Hummelen, W. M. H. Amsterdams toneel in het begin van de Gouden Eeuw: Studies over Het Wit Lavendel en de Nederduytsche Academie. The Hague: Nijhoff, 1982.

Jaarverslag Gemeentearchief Amsterdam. Amsterdam, 1873.

Kilian, K. "De Haarlemse loterij van 1606-1607: Loterijen en loterijrijmpjes." Haerlem Jaarboek (1989): 8-37.

Mander, K. van. "Den grondt der edel vry schilder-const." In Schilder-boeck," ed. H. Miedema. Haarlem, 1604; repr. Utrecht: Haentjes Dekker \& Gumbert, 1973.

Meskens, A. Familia Universalis: Coignet; Een familie tussen wetenschap en kunst. Exh. cat. Antwerp: Koninklijk Museum voor Schone Kunsten, 1998.

Middelkoop, N. E.,et.al. De oude meesters van de Stad Amsterdam: Schilderijen tot 1800. Bussum: Thoth, 2008.

Miedema, H. "Nog een schilderij van Gillis Coignet: Judith toont het hoofd van Holofernes aan de inwoners van Bethulië." Oud Holland 109 (1995): 143-51. doi:10.1163/187501795X00223

Neumeister, M. Das Nachtstück mit Kunstlicht in der niederländischen Malerei und Graphik des 16. und 17. Jahrhunderts. Petersberg: Michael Imhoff, 2003.

Orenstein, N. M. Pieter Bruegel the Elder (The New Holstein...). Ouderkerk aan de IJssel: Sound \& Vision, 2006

Pontanus, J. W. Historische beschrijvinghe der seer wijt beroemde Coop-stadt Amsterdam. Amsterdam: J. Hondius, 1614.

Roever, N. de. "De rariteiten-kamer verbonden aan 't Amsterdamsche Gemeente-archief.' Oud Holland 6 (1888): 195-224.

Sander, C. A. L. "Het Dulhuys of Dolhuis aan de vesten of de Kloveniersburgwal." Maandblad Amstelodamum 45 (1958): 229-38.

Snoep, D. P. Praal en propaganda: Triumfalia in de Noordelijke Nederlanden in de 16e en 17 e eeuw. Alphen a/d Rijn: Canaletto, 1975. 
Spies, M. "Centrum van de wereld: 1587-1650." In Geschiedenis van Amsterdam, eds. W. Frijhoff and M. Prak, vol. 2-1:307. Amsterdam: SUN, 2005.

Vermeer, G. "Het Dolhuis in Amsterdam en het tomen van de razernij." Idem 94-5 (2007): 3-18.

Wagenaar, J. Amsterdam, In Zyne Opkomst, Aanwas, Geschiedenissen, Voorregten, Koophandel, Gebouwen, Kerkenstaat, Schoolen, Schutterye, Gilden En Regeeringe. Vol. 2. Amsterdam: Tirion, 1765.

Zeven spelen van die Wercken van Bermherticheyd. In rijm gemaeckt en nu tot Aemstelredam opentlijck ghespeelt, Anno 1591. T'Aemstelredam, bij mij Herman Jansz. Muller, figuersnijder, woonende in de Warmoesstaraat in den vergulden Passer, Anno 1591. Amsterdam, Herman Jansz Muller, 1591.

Recommended Citation:

Norbert Middlekoop, "Gillis Coignet and the Amsterdam Lottery of 1592: Locating an Extraordinary Night Scene," JHNA 2:1-2 (2010), D0l: 10.5092/jhna.2010.2.1.4 